\title{
Determination of Some Agronomic and Fruit Quality Characteristics of Some Watermelon Accessions from Turkish Watermelon Germplasm
}

\author{
Ercüment Atlı ${ }^{1, a}$, İlknur Solmaz ${ }^{2, b, *}$, Nebahat Sarı ${ }^{2, c}$, Haşim Kelebek $^{3, d}$ \\ ${ }^{1}$ Metgen Seed Company, 34750 Istanbul, Turkey \\ ${ }^{2}$ Department of Horticulture, Faculty of Agriculture, Çukurova University, 01330 Adana, Turkey \\ ${ }^{3}$ Department of Food Engineering, Faculty of Engineering, Adana Alparslan Türkeş Science and Technology University, 01250 Adana, Turkey \\ *Corresponding author
}

A R T I C L I N F O A B S T R A T

Research Article

This study has been conducted to determine the fruit quality parameters such as sugar and carotenoid content as well as plant and fruit characteristics of 11 local watermelon genotypes from watermelon genetic resources collection of Cukurova University, Department of Horticulture. First and $50 \%$ male and female flowering period, main stem length, main stem diameter, number of nodes

Received : 15/05/2019

Accepted : 09/07/2021 on main stem, total yield, fruit weight, fruit length, fruit diameter, fruit rind thickness, total soluble solids (TSS), sugar and carotenoid contents were examined. Although there is no significant difference for main stem diameter and number of nodes on the main stem, significant differences were obtained for total yield, sugar and carotenoid composition of the genotypes. Carotenoid and sugar analysis were performed with a high-performance liquid chromatographic method coupled

Keywords:

Watermelon

Local genotypes

Fruit properties

Sugar

Carotenoids with diode-array detector (HPLC-DAD) and HPLC coupled with refractive index detector (RID), respectively. In all studied genotypes, cis-13-lycopene and $\beta$-carotene were the most abundant compounds. As expected for watermelon genotypes, the main sugar found in all studied genotypes was fructose. According to PCA analyses, genotypes were characterized by physical and chemical composition. Overall evaluation of results revealed that Kar 147 had better potential with carotenoid, sugar contents and fruit characteristics.

ercumentatli@gmail.com nesari@cu.edu.tr
(iD)https://orcid.org/0000-0003-0307-3304|b_isolmaz@cu.edu.tr (iD) htps://orcid.org/0000-0001-7112-4279|d hkelebek@adanabtu.edu.tr https://orcid.org/0000-0003-2996-0286 https://orcid.org/0000-0002-8419-3019

\section{(c) 8 (i) (9) This work is licensed under Creative Commons Attribution 4.0 International License}

\section{Introduction}

Watermelon, [Citrullus lanatus (Thunb.) Matsum. and Nakai] is an important species with high economic value belongs to the Cucurbitaceae family. In the world, 100414 933 tons of watermelons are produced in 3084217 ha area. In Turkey, to the production amount is 3870515 tons on 87 990 ha area (FAO, 2019).

Genetic resources can be grouped into three categories as wild species, local genotypes and modern varieties (Tanksley and McCouch, 1997). Local genotypes may perform poorly in terms of quality and yield compared to modern varieties but they are very functional for the development of new varieties due to their genetic richness. The collection and conservation of local genetic material is a crucial step in the event of sustainable agriculture (Krasteva, 2000).

Since 1993, approximately 400 watermelon genetic materials were collected from different regions of Turkey, brought from different countries and provided from foreign gene banks and preserved in Cukurova University Faculty of
Agriculture, Department of Horticulture. These genotypes were morphologically (Sari et al., 2007; Solmaz et al., 2009) and genetically (Solmaz et al., 2010) characterized. In a previous study (Solmaz et al., 2012), some of them were selected and regenerated for using in further breeding studies. However, since date, their sugar and carotenoid contents have not been examined.

Carotenoids have been associated with the reduction of the risks of various chronic degenerative disorders, such as cancer, inflammations, cardiovascular diseases, cataracts, and macular degeneration. These compounds are an abundant group of lipid antioxidants. $\beta$-carotene is the source of vitamin A (Yoo et al., 2012; Kim et al., 2014).

Carotenoids are responsible for the different flesh colors in watermelon. The carotenoid profiles of red, white, yellow, and orange fleshed watermelons have been characterized. Lycopene constitutes the major and $\beta$-carotene is the secondary pigment in red fleshed watermelons. Neoxanthin 
is determined to be the pre-dominant carotenoid in yellowfleshed watermelon (Zhao et al., 2013, Ilahy et al., 2019)

Carotenoid content in watermelons is genotypedependent, and seedless triploid watermelons contain more lycopene than the seeded diploids (Perkins-Veazie et al., 2006).

Sugars are the significant components of watermelon fruit quality; they form soluble solids and sweetness of the watermelon is intrinsic to its sugar composition. Fructose, followed by glucose, and sucrose, is present in the largest amounts in watermelon (Kim et al., 2014).

The aim of this study was to investigate the yield, agronomic performances and some fruit quality characters of watermelon genotypes which belong to the watermelon genetic resources collection of Cukurova University Faculty of Agriculture Department of Horticulture.

\section{Materials and Methods}

This study was conducted at the open field in the Research and Application area of Çukurova University. Sugar and carotenoid were analysed in laboratories of Food Engineering Department of Adana Alparslan Türkeş Science and Technology University.

\section{Plant Material and Field Experiment}

The names and origins of the genotypes used in the study are presented in Table 1 . These 11 genotypes belong to the watermelon genetic resources collection of Cukurova University, Faculty of Agriculture, Department of Horticulture. They are selected due to their high agronomic performance and uniformity. A hundred seeds of each genotype were sown on 13 May 2015 at a private nursery (Ender Seedling, Mersin, Turkey). Seedlings were planted at 3-4 true leaf stage on 8 June 2015 in open field with a spacing of $2 \mathrm{~m}$ between rows and $0.5 \mathrm{~m}$ within rows. The experimental design was randomized blocks with four replications and ten plants were used in each replication. A drip irrigation system was established and plants were fertilized by $\mathrm{N}: \mathrm{P}_{2} \mathrm{O}_{5}: \mathrm{K}_{2} \mathrm{O}$ according to $15: 10: 20 \mathrm{~kg} /$ da pure ratio (Solmaz et al., 2012). Weeds were controlled by hand and fungicides and insecticides were applied against anthracnose and white fly. The first harvest was on 20 August 2015 and the second harvest was on 31 August 2015. First and 50\% male and female flowering period was controlled daily for each genotype. Main stem length $(\mathrm{cm})$, main stem diameter $(\mathrm{mm})$, the number of nodes on the main stem were determined in 3 plants in each replication with a meter and a digital caliper (Mitutoyo CD-15D).
Total yield $\left(\mathrm{kg} / \mathrm{m}^{2}\right)$, fruit weight $(\mathrm{g})$ fruit length $(\mathrm{cm})$, fruit diameter $(\mathrm{cm})$, rind thickness $(\mathrm{mm})$ and total soluble solids content (\%) were measured in 3 fruits from each replication. Measurements were carried out by a ruler, digital caliper (Mitutoyo CD-15D), and digital refractometer (ATAGO Pocket PAL-31).

\section{Liquid Chromatography Analysis of Sugars}

A HPLC system (Agilent 1260 HPLC system; Agilent Technologies, Palo Alto, California, USA) equipped with a pump system and a refractive index detector (G1362A RID) was used for sugar analysis. Aminex HPX-87H column $(300 \times 7.8 \mathrm{~mm})$ (Bio-Rad, California, USA) was used for analysis. The analytical conditions were as follows: flow $0.6 \mathrm{~mL} / \mathrm{min}$, eluent $0.09 \mathrm{~mol} / \mathrm{L} \mathrm{H} 2 \mathrm{SO} 4$ with $6 \%$ acetonitrile (v/v). A calibration curve was prepared using standards to determine the relationship between the peak area and concentration (Kumar et. al., 2012).

\section{Liquid Chromatography Analysis of Carotenoids}

Samples were prepared using ethanol-hexane $(5: 4, v / v)$ as described by (Li et al., 2011) for carotenoid analysis. Briefly, the homogenate was sonicated for 5 minutes and centrifuged at $4500 \mathrm{rpm}$ for 15 minutes at $4^{\circ} \mathrm{C}$. The supernatant was transferred into a flask and the extraction was repeated. An Agilent 6430 LC-MS/MS spectrometer equipped with an electrospray ionization source, which was described in phenolic compounds analyses, was used for carotenoid analysis. The separation of carotenoids was conducted using a C30 carotenoid column $(250 \times 4.6 \mathrm{~mm}$ i.d., $5 \mu \mathrm{m}$, YMC, Kyoto, Japan). Carotenoids were separated and identified according to the procedure described by Kelebek et al. (2017).

\section{Statistical Analysis}

The obtained data were analyzed using the statistical software JMP (v8.00, SAS Institute Inc., NC 27513-2414, USA). ANOVA was carried out to determine the effects of the rootstocks and years on examined parameters. The least significant difference test was performed to examine differences among the different groups. Comparisons that yielded $* * *=\mathrm{P} \leq 0.001, * *=\mathrm{P} \leq 0.01$ and $*=\mathrm{P} \leq 0.05$ were considered to be statistically significant. Principal component analysis (PCA) was performed to see the classification pattern of the samples according to sugar and carotenoid compounds. The data matrix consisted of watermelon genotypes as observations and components of genotypes as variables. PCA score and loading plots were constructed for visual interpretation of the results. All results were analyzed using Minitab $^{\circledR} 17$ programme (Minitab Inc., State College, USA).

Table 1 . The name and origin of the watermelon genotypes used in the study

\begin{tabular}{l|cc}
\hline Genotype & Name & Origin \\
\hline Kar 23 & Tat karpuzu & Şanliurfa \\
Kar 58 & TR 48528 & AARI \\
Kar 59 & TR 48544 & AARI \\
Kar 98 & No name & Şanliurfa \\
Kar 102 & No name & Nusaybin-Cizre \\
Kar 116 & No name & Nusaybin-Cizre \\
Kar 117 & No name & Şanluurfa \\
Kar 147 & Medine Karpuzu & Şanliurfa \\
Kar 154 & No name & Batman \\
Kar 175 & No name & Manisa \\
Kar 180 & No name & Manisa \\
\hline
\end{tabular}




\section{Results and Discussion}

Days to first and $50 \%$ flowering period of male and female flowers of the watermelon genotypes were recorded and presented in Table 2. According to the results, significant differences were found between the genotypes. The first male flower was observed in the genotypes Kar 23 and Kar 175 (23.50 days after transplanting) and the first female flower was found in the genotype Kar 23 (27.00 days after transplanting). In terms of days to $50 \%$ male flowering Kar 23, Kar 58 and Kar 175 were earlier (26.50, 26.25 and 26.25 days respectively) than other genotypes. Considering days to $50 \%$ female flowering Kar 23 and Kar 58 found to be the earliest (29.25 days) genotypes. Our results are similar to (Gichimu et. al., 2008) who reported that male flowers opened 6-13 days earlier than female flowers. There was a significant difference among genotypes for main stem length (Table 3). The longest main stem was determined in Kar 23 with $142.15 \mathrm{~cm}$ and the shortest was in Kar 116 with 98.40 $\mathrm{cm}$. Even though there were no significant differences among the genotypes, the diameter of the main stem ranged from 7.47 to $9.60 \mathrm{~mm}$ and the number of nodes were between 18.25 and 21.50. Our results in the main stem diameter were lower than those of Karipçin (2009) who found the main stem diameter values between 17.24-35.23 $\mathrm{mm}$. The same researcher reported the number of nodes on the main stem as varied between 19 to 21.5 which is inconsistent with our findings.

Total yield, average fruit weight, fruit length, fruit diameter, fruit rind thickness and TSS were measured and results were presented in Table 4 . According to the results of variance analysis, significant differences were found between genotypes in terms of all measured fruit parameters. The highest yields were obtained from $\operatorname{Kar} 23\left(4.28 \mathrm{~kg} / \mathrm{m}^{2}\right)$ and $\operatorname{Kar} 154\left(4.25 \mathrm{~kg} / \mathrm{m}^{2}\right)$ respectively while Kar 116 had the lowest yield $\left(1.36 \mathrm{~kg} / \mathrm{m}^{2}\right)$. Average fruit weight of the genotypes ranged from $1775 \mathrm{~g}$ (Kar 180) to $4274 \mathrm{~g}$ (Kar 154). Comparable results were reported by Maggs-Kolling and Christiansen (2003), who found the lowest and the highest yield as $1.78-3.34 \mathrm{~kg} / \mathrm{m}^{2}$. The highest fruit length was $26.83 \mathrm{~cm}$ and obtained from Kar 23 while the shortest was $15.17 \mathrm{~cm}$ and found in Kar 180. Our findings were lower than those of Erdem et al. (2001) who reported the average fruit length in watermelons ranged from $22.55 \mathrm{~cm}$ to $39.60 \mathrm{~cm}$. The differences are attributed to different genotypes and climatic conditions. In terms of fruit diameter, Kar 154 had the widest $(19.19 \mathrm{~cm})$ fruits and Kar $180(14.49 \mathrm{~cm})$ had the lowest diameter ue among watermelon genotypes. The thinnest fruit rind $(8.77 \mathrm{~mm})$ was recorded in Kar 180 while the thickest $(15.25 \mathrm{~mm}$ ) was found in Kar 154. Our results are in agreement with Gusmuni et al. (2004) who reported the fruit rind thickness of 9 local and 103 commercial watermelon varieties thicker than $10 \mathrm{~mm}$. The TSS content of the genotypes were ranged from $5.57 \%$ to $8.03 \%$. These values are lower than different studies (Schulteis et al., 2007; Yuan-feng et al., 2013) in which TSS content of watermelons were between $10.6 \%$ $12 \%$ and $12 \%-12.5 \%$ respectively. The differences may be due to a different type of plant materials used as commercial varieties and genetic resources.

Table 2. Days to first and 50\% male and female flowering of the watermelon genotypes used in the study (number of days since planting)

\begin{tabular}{|c|c|c|c|c|}
\hline Genotype & Days to first male flower & Days to first female flower & Days to $50 \%$ male flower & Days to $50 \%$ female flower \\
\hline$\overline{\text { Kar } 23}$ & $23.50^{\mathrm{d}}$ & $27.00^{\mathrm{c}}$ & $26.50^{\mathrm{e}}$ & $29.25^{\mathrm{g}}$ \\
\hline Kar 58 & $24.25^{\mathrm{cd}}$ & $28.00^{\mathrm{bc}}$ & $26.25^{\mathrm{e}}$ & $29.25^{\mathrm{g}}$ \\
\hline Kar 59 & $25.75^{\mathrm{bc}}$ & $29.25^{\mathrm{b}}$ & $29.25^{\mathrm{bc}}$ & $31.25^{\mathrm{d}-\mathrm{f}}$ \\
\hline Kar 98 & $25.75^{\mathrm{bc}}$ & $28.75^{\mathrm{b}}$ & $28.50^{\mathrm{b}-\mathrm{d}}$ & $31.00^{\mathrm{ef}}$ \\
\hline Kar 102 & $26.00^{\mathrm{b}}$ & $29.25^{\mathrm{b}}$ & $28.75^{\mathrm{b}-\mathrm{d}}$ & $33.00^{\mathrm{b}}$ \\
\hline Kar 116 & $31.00^{\mathrm{a}}$ & $34.00^{\mathrm{a}}$ & $35.50^{\mathrm{a}}$ & $40.00^{\mathrm{a}}$ \\
\hline Kar 117 & $25.00^{\mathrm{b}-\mathrm{d}}$ & $28.25^{\mathrm{bc}}$ & $27.50^{\mathrm{de}}$ & $31.25^{\mathrm{d}-\mathrm{f}}$ \\
\hline Kar 147 & $25.25^{\mathrm{bc}}$ & $29.25^{\mathrm{b}}$ & $29.75^{\mathrm{b}}$ & $32.50^{\mathrm{bc}}$ \\
\hline Kar 154 & $24.50^{\mathrm{b}-\mathrm{d}}$ & $28.50^{\mathrm{bc}}$ & $27.75^{\mathrm{c}-\mathrm{e}}$ & $31.50^{\text {cde }}$ \\
\hline Kar 175 & $23.50^{\mathrm{d}}$ & $28.00^{\mathrm{bc}}$ & $26.25^{\mathrm{e}}$ & $30.25^{\mathrm{fg}}$ \\
\hline Kar 180 & $24.50^{\mathrm{b}-\mathrm{d}}$ & $28.75^{b}$ & $28.50^{\mathrm{b}-\mathrm{d}}$ & $32.25^{\mathrm{b}-\mathrm{d}}$ \\
\hline LSD & $1.56 * * *$ & $1.72 * * *$ & $1.72 * * *$ & $1.23 * *$ \\
\hline
\end{tabular}

(1): The differences between the averages are shown in separate letters. (2): ***: $\mathrm{P}<0.001 ; * *: \mathrm{P}<0.01$

Table 3. The main stem length, the main stem diameter and the number of nodes on the main stem of the watermelon genotypes used in the study

\begin{tabular}{l|ccc}
\hline Genotype & Main stem length $(\mathrm{cm})$ & Main stem diameter $(\mathrm{mm})$ & Number of nodes on the main stem \\
\hline Kar 23 & $142.15^{\mathrm{a}}$ & 9.60 & 19.75 \\
Kar 58 & $139.73^{\mathrm{ab}}$ & 8.23 & 21.00 \\
Kar 59 & $126.63^{\mathrm{abc}}$ & 8.59 & 20.00 \\
Kar 98 & $123.15^{\mathrm{a}-\mathrm{d}}$ & 7.95 & 21.50 \\
Kar 102 & $117.81^{\mathrm{a}-\mathrm{d}}$ & 8.73 & 18.25 \\
Kar 116 & $98.40^{\mathrm{d}}$ & 8.71 & 21.25 \\
Kar 117 & $115.66^{\text {bcd }}$ & 7.79 & 20.25 \\
Kar 147 & $110.43^{\mathrm{cd}}$ & 9.09 & 19.75 \\
Kar 154 & $124.23^{\mathrm{abc}}$ & 8.98 & 21.00 \\
Kar 175 & $98.83^{\mathrm{d}}$ & 8.18 & 19.00 \\
Kar 180 & $106.87^{\mathrm{cd}}$ & 7.47 & 21.25 \\
LSD & $25.4^{*}$ & N.S. & N.S. \\
\hline
\end{tabular}

(1): The differences between the averages are shown in separate letters. (2): N.S.: Non-Significant; *: P<0.05 
Table 4. Total yield $\left(\mathrm{kg} / \mathrm{m}^{2}\right)$ and fruit characteristics of the watermelon genotypes used in the study

\begin{tabular}{l|ccccc}
\hline Genotype & Yield $\left(\mathrm{kg} / \mathrm{m}^{2}\right)$ & Fruit Weight $(\mathrm{kg})$ & Fruit length $(\mathrm{cm})$ & Fruit diameter $(\mathrm{cm})$ & Fruit rind thickness $(\mathrm{mm})$ \\
\hline Kar 23 & $4.28^{\mathrm{a}}$ & $3036^{\mathrm{bc}}$ & $26.83^{\mathrm{a}}$ & $15.10^{\mathrm{cd}}$ & $12.13^{\mathrm{b}}$ \\
Kar 58 & $1.99^{\mathrm{de}}$ & $2540^{\mathrm{b}-\mathrm{d}}$ & $17.17^{\mathrm{de}}$ & $16.70^{\mathrm{bc}}$ & $12.35^{\mathrm{ab}}$ \\
Kar 59 & $3.72^{\mathrm{ab}}$ & $3250^{\mathrm{bc}}$ & $18.15^{\mathrm{cd}}$ & $17.96^{\mathrm{ab}}$ & $11.01^{\mathrm{bc}}$ \\
Kar 98 & $2.99^{\mathrm{bc}}$ & $2710^{\mathrm{bc}}$ & $18.69^{\mathrm{cd}}$ & $16.37^{\mathrm{b}-\mathrm{d}}$ & $9.89^{\mathrm{bc}}$ \\
Kar 102 & $2.16^{\mathrm{c}-\mathrm{e}}$ & $3121^{\mathrm{bc}}$ & $21.67^{\mathrm{b}}$ & $14.99^{\mathrm{cd}}$ & $10.79^{\mathrm{bc}}$ \\
Kar 116 & $1.36^{\mathrm{e}}$ & $2722^{\mathrm{bc}}$ & $18.31^{\mathrm{cd}}$ & $16.39^{\mathrm{b}-\mathrm{d}}$ & $12.43^{\mathrm{ab}}$ \\
Kar 117 & $1.85^{\mathrm{de}}$ & $2888^{\mathrm{bc}}$ & $21.21^{\mathrm{b}}$ & $16.04^{\mathrm{b}-\mathrm{d}}$ & $10.58^{\mathrm{bc}}$ \\
Kar 147 & $2.05^{\mathrm{c}-\mathrm{e}}$ & $3308^{\mathrm{b}}$ & $20.12^{\mathrm{bc}}$ & $17.56^{\mathrm{ab}}$ & $9.75^{\mathrm{bc}}$ \\
Kar 154 & $4.25^{\mathrm{a}}$ & $4274^{\mathrm{a}}$ & $20.26^{\mathrm{bc}}$ & $19.19^{\mathrm{a}}$ & $15.25^{\mathrm{a}}$ \\
Kar 175 & $2.52^{\mathrm{cd}}$ & $2410^{\mathrm{cd}}$ & $16.81^{\mathrm{de}}$ & $16.08^{\mathrm{b}-\mathrm{d}}$ & $12.36^{\mathrm{ab}}$ \\
Kar 180 & $1.47^{\mathrm{e}}$ & $1775^{\mathrm{d}}$ & $15.17^{\mathrm{e}}$ & $14.49^{\mathrm{d}}$ & $8.77^{\mathrm{c}}$ \\
LSD & $0.98^{* * *}$ & $885.53^{* * *}$ & $2.50^{* * *}$ & $1.93^{* * *}$ & $2.92^{* *}$ \\
\hline
\end{tabular}

(1): The differences between the averages are shown in separate letters. (2): ***:P<0.001; **:P<0.01

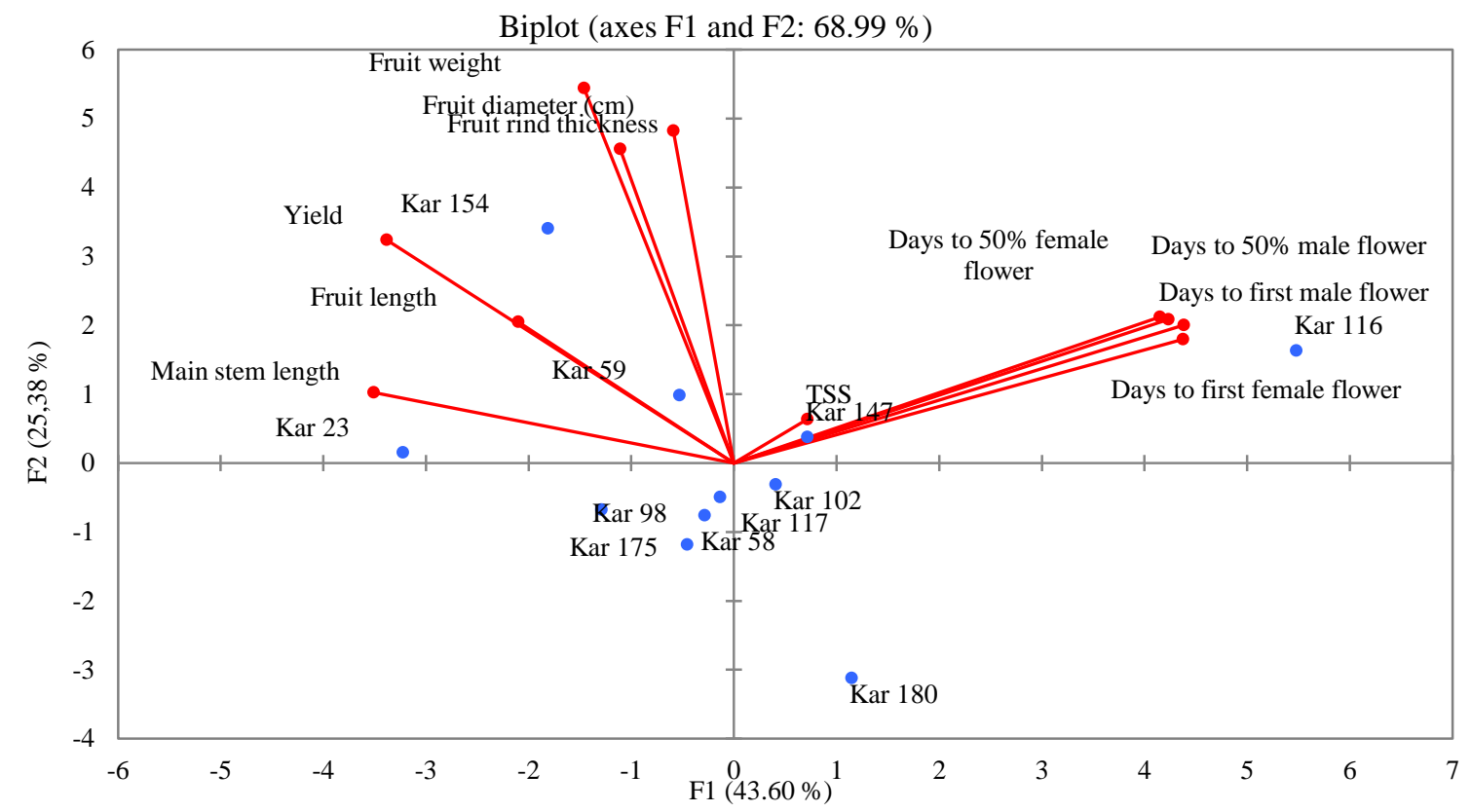

Figure 1a. Principal components analysis biplot for the first two principal components of physical properties

PCA was performed in order to check the validity of the flowering period of male and female flowers and physical properties of fruits to discriminate watermelons according to the genotypes (Figure 1a). The PCA model was constructed with four PCs accounting for $68.99 \%$ of the total variability. PC1 and PC2 explain 46.60 and $25.18 \%$ of total variance, respectively. A PCA biplot including score and loading plots with two principal components is illustrated in Figure 1a. As can be seen according to the results of the analysis, there was no significant distinction between genotypes.

\section{Sugars}

Watermelon flavor is conditioned, in part, by the balance between sugars and acids expressed in ripe fruits, and the sugars are the important contributors to the soluble solids of watermelon. Sucrose, glucose and fructose were determined as sugar components (Table 5) and statistically significant differences were found between the genotypes. The amount of sugars detected were in the order of fructose $>$ glucose $>$ sucrose. The sucrose content was between $0.37 \mathrm{~g} \mathrm{~kg}^{-1}$ (Kar 59) and $30.09 \mathrm{~g} \mathrm{~kg}^{-1}$ (Kar 147). The highest value in terms of glucose content was obtained from the genotype Kar 154 (30.67 $\left.\mathrm{g} \mathrm{kg}^{-1}\right)$. Considering fructose,
Kar 58 (42.99 $\mathrm{g} \mathrm{kg}^{-1}$ ) had the highest amount. Regarding total sugar content, it was observed that Kar $147\left(87.97 \mathrm{~g} \mathrm{~kg}^{-}\right.$ ${ }^{1}$ ) had the highest value. Cultivars or maturity that results in high fructose concentrations is a desirable feature since the relative sweetness of fructose is greater than that of sucrose.

The relative concentration of these sugars is important since they vary in perceived sweetness. Compared to the data available in the literature, the analyzed sugar content of watermelon cultivar was similar to the sweet cherries grown in other countries (Liu et al., 2012)

\section{Carotenoids}

Carotenoids, which impart yellow, orange, and/or red colors to watermelon fruits, have antioxidant properties. Results of the carotenoid analysis are presented in Table 6. Luteolin, phytofluene A, phytoene, phytofluen $\mathrm{B}, \beta$ carotene, cis-15-lycopene, cis-13-lycopene and all-trans lycopene were determined and found to be statistically different among genotypes. The highest value of luteolin, phytofluene A, phytoene, phytofluene B, cis-15-lycopene, cis-13-lycopene and all-trans lycopene content was found in Kar 175. In terms of $\beta$-carotene, the highest content was obtained in Kar 98 (15.19 $\left.\mathrm{mg} \mathrm{kg}^{-1}\right)$. The genotypes showed 
remarkable variation in lycopene content ranging from 0.20 $\mathrm{mg} \mathrm{kg}^{-1}$ (Kar 180) to $145.26 \mathrm{mg} \mathrm{kg}^{-1}$ (Kar 175). Phytofluene was correlated with total lycopene and $\beta$-carotene. All-translycopene was less well-correlated with cis-lycopene or with $\beta$-carotene, as cis-lycopene and $\beta$-carotene did not always increase proportionally with lycopene. Total carotenoid content and phytofluene generally increased in proportion to total lycopene content, as phytofluene is a required precursor for both carotenoids (Perkins-Veazie et al., 2006). The lycopene content in commercial red-fleshed watermelons has been reported to be 45.1-53.2 $\mu \mathrm{g} \mathrm{g}^{-1}$ fresh weight (FW), mean value $48.2 \mu \mathrm{g} \mathrm{g}^{-1}$. These values are $60 \%$ higher than those reported for tomatoes $\left(30.2 \mu \mathrm{g} \mathrm{g}^{-1} \mathrm{FW}\right.$ ) (Zhao et al., 2013). Lycopene content varied widely among cultivars, in red-fleshed cultivars lycopene content was reported between 33.9 and $75.7 \mu \mathrm{g} \mathrm{g}^{-1}$ (mean value $50 \mu \mathrm{g} \mathrm{g}^{-1}$ ); the two yellowfleshed varieties having lower than $5 \mu \mathrm{g} \mathrm{\textrm {g } ^ { - 1 }}$ lycopene (Perkins-Veazie et al., 2006). In other study, lycopene content of 50 commercial cultivars of red-fleshed watermelon reported $70-90 \mathrm{mg} \mathrm{kg}^{-1}$ of lycopene, very high cultivars $>90 \mathrm{mg} \mathrm{kg}^{-1}$ of lycopene, and the highest $120 \mathrm{mg}$ $\mathrm{kg}^{-1}$ of lycopene, and that red-fleshed seedless watermelon cultivars were most often high in lycopene. Besides genotype and ploidy level, lycopene content in watermelon is related to harvest maturity and growth and development conditions. Environmental conditions during production, such as light intensity, day/night temperature, irrigation, and soil fertility, can change lycopene content by $10-20 \%$ (Perkins-Veazie et al., 2006).

The correlation results of some important fruit quality parameters are shown in Table 7. According to these results, there was found positive correlation between TSS and total sugar content of fruits expected. At the same time, it was determined that there was positive correlation between total carotenoids and sugars. This result indicates that the amount of carotenoids is depended on sugar content of fruits.

PCA was performed in order to check the validity of sugar and carotenoid contents results to discriminate watermelon genotypes according to the component of the genotypes (Figure 1b). The PCA model was constructed with four PCs accounting for $86.37 \%$ of the total variability. PC1 and PC2 explain 65.46 and $20.91 \%$ of the total variance, respectively. A PCA biplot including score and loading plots with two principal components is illustrated in Figure 1b. As can be seen in Kar 147, Kar 98, Kar 117 and especially Kar 175 are characterized by cis-13-lycopene, cis15-lycopene, $\beta$-carotene, phytoene, phytofluene A, phytofluene, luteolin, all-trans lycopene.

Table 5. Results of sugar analysis of watermelon genotypes used in the study $\left(\mathrm{g} \mathrm{kg}^{-1}\right)$

\begin{tabular}{|c|c|c|c|c|c|}
\hline Genotype & Sucrose & Glucose & Fructose & Total sugars sugars & TSS (\%) \\
\hline Kar 23 & $5.88^{f}$ & $28.23^{\mathrm{b}}$ & $33.63^{\mathrm{d}}$ & $67.74^{\mathrm{f}}$ & $5.73^{\mathrm{de}}$ \\
\hline Kar 58 & $9.97^{\mathrm{e}}$ & $28.63^{\mathrm{b}}$ & $42.99^{\mathrm{a}}$ & $81.59^{\mathrm{b}}$ & $7.37^{\mathrm{ab}}$ \\
\hline Kar 59 & $0.37^{1}$ & $17.71^{\mathrm{g}}$ & $26.24^{\mathrm{e}}$ & $44.32^{\mathrm{h}}$ & $5.57^{\mathrm{e}}$ \\
\hline Kar 98 & $12.37^{\mathrm{d}}$ & $24.56^{\mathrm{c}}$ & $39.47^{\mathrm{b}}$ & $76.40^{\mathrm{cd}}$ & $7.03^{\mathrm{bc}}$ \\
\hline Kar 102 & $4.70^{\mathrm{g}}$ & $17.62^{\mathrm{g}}$ & $34.96^{\mathrm{cd}}$ & $57.28^{\mathrm{g}}$ & $6.50^{\mathrm{b}-\mathrm{e}}$ \\
\hline Kar 116 & $1.92^{\mathrm{h}}$ & $21.26^{\mathrm{e}}$ & $36.36^{\mathrm{c}}$ & $59.54^{\mathrm{g}}$ & $6.69^{\mathrm{bcd}}$ \\
\hline Kar 117 & $19.66^{\mathrm{b}}$ & $22.60^{\mathrm{d}}$ & $33.52^{\mathrm{d}}$ & $75.78^{\mathrm{cd}}$ & $6.45^{\mathrm{b}-\mathrm{e}}$ \\
\hline Kar 147 & $30.09^{a}$ & $21.44^{\text {de }}$ & $36.44^{\mathrm{c}}$ & $87.97^{\mathrm{a}}$ & $8.03^{\mathrm{a}}$ \\
\hline Kar 154 & $5.23^{\mathrm{fg}}$ & $30.67^{\mathrm{a}}$ & $42.41^{\mathrm{a}}$ & $78.31^{b c}$ & $6.93^{\mathrm{bc}}$ \\
\hline Kar 175 & $16.74^{\mathrm{c}}$ & $19.46^{\mathrm{f}}$ & $35.68^{c}$ & $71.88^{\mathrm{e}}$ & $7.03^{\mathrm{bc}}$ \\
\hline Kar 180 & $9.95^{\mathrm{e}}$ & $24.05^{\mathrm{c}}$ & $39.45^{\mathrm{b}}$ & $73.45^{\mathrm{de}}$ & $6.06^{\mathrm{cde}}$ \\
\hline LSD & $0.69 * * *$ & $1.21 * * *$ & $1.91 * * *$ & $3.66 * * *$ & $0.99 * * *$ \\
\hline
\end{tabular}

(1): The differences between the averages are shown in separate letters. (2): ***:P<0.001; **:P<0.01

Table 6. Results of carotenoid analysis of watermelon genotypes used in the study $\left(\mathrm{mg} \mathrm{kg}^{-1}\right)$

\begin{tabular}{l|cccccccc}
\hline Genotype & \multicolumn{7}{c}{ cis-13-Lycopene cis-15-Lycopene $\beta$-CarotenePhytoenePhytofluene APhytofluene BLuteolinAll-trans lycopene } \\
\hline Kar 23 & $3.59^{\mathrm{f}}$ & $0.69^{\mathrm{f}}$ & $1.25^{\mathrm{fg}}$ & $1.79^{\mathrm{f}}$ & $0.51^{\mathrm{h}}$ & $0.30^{\mathrm{f}}$ & $0.41^{\mathrm{g}}$ & $42.38^{\mathrm{g}}$ \\
Kar 58 & $8.54^{\mathrm{d}}$ & $1.49^{\mathrm{d}}$ & $2.55^{\mathrm{ef}}$ & $2.55^{\mathrm{d}}$ & $0.70^{\mathrm{f}}$ & $0.42^{\mathrm{c}}$ & $0.52^{\mathrm{e}}$ & $89.47^{\mathrm{d}}$ \\
Kar 59 & $8.95^{\mathrm{d}}$ & $1.46^{\mathrm{d}}$ & $3.73^{\mathrm{de}}$ & $2.84^{\mathrm{c}}$ & $0.77^{\mathrm{e}}$ & $0.38^{\mathrm{d}}$ & $0.65^{\mathrm{c}}$ & $70.28^{\mathrm{e}}$ \\
Kar 98 & $13.34^{\mathrm{b}}$ & $2.28^{\mathrm{b}}$ & $15.19^{\mathrm{a}}$ & $3.24^{\mathrm{b}}$ & $1.10^{\mathrm{b}}$ & $0.38^{\mathrm{d}}$ & $0.61^{\mathrm{d}}$ & $117.51^{\mathrm{b}}$ \\
Kar 102 & $6.59^{\mathrm{e}}$ & $1.54^{\mathrm{d}}$ & $4.90^{\mathrm{cd}}$ & $2.59^{\mathrm{d}}$ & $0.60^{\mathrm{g}}$ & $0.36^{\mathrm{de}}$ & $0.57^{\mathrm{d}}$ & $52.61^{\mathrm{f}}$ \\
Kar 116 & $0.56^{\mathrm{g}}$ & $0.00^{\mathrm{g}}$ & $0.00^{\mathrm{g}}$ & $0.67^{\mathrm{g}}$ & $0.00^{1}$ & $0.00^{\mathrm{g}}$ & $0.00^{\mathrm{h}}$ & $6.70^{\mathrm{h}}$ \\
Kar 117 & $12.08^{\mathrm{c}}$ & $1.85^{\mathrm{c}}$ & $5.12^{\mathrm{cd}}$ & $3.29^{\mathrm{b}}$ & $0.88^{\mathrm{d}}$ & $0.46^{\mathrm{b}}$ & $0.70^{\mathrm{b}}$ & $108.33^{\mathrm{c}}$ \\
Kar 147 & $11.98^{\mathrm{c}}$ & $1.95^{\mathrm{c}}$ & $5.92^{\mathrm{c}}$ & $3.38^{\mathrm{b}}$ & $0.99^{\mathrm{c}}$ & $0.49^{\mathrm{b}}$ & $0.71^{\mathrm{b}}$ & $138.38^{\mathrm{a}}$ \\
Kar 154 & $4.22^{\mathrm{f}}$ & $1.08^{\mathrm{e}}$ & $0.80^{\mathrm{g}}$ & $2.04^{\mathrm{e}}$ & $0.57^{\mathrm{h}}$ & $0.34^{\mathrm{e}}$ & $0.47^{\mathrm{f}}$ & $45.88^{\mathrm{fg}}$ \\
Kar 175 & $15.49^{\mathrm{a}}$ & $2.74^{\mathrm{a}}$ & $12.31^{\mathrm{b}}$ & $3.88^{\mathrm{a}}$ & $1.24^{\mathrm{a}}$ & $0.74^{\mathrm{a}}$ & $0.81^{\mathrm{a}}$ & $145.26^{\mathrm{a}}$ \\
Kar 180 & $0.14^{\mathrm{g}}$ & $0.00^{\mathrm{g}}$ & $0.06^{\mathrm{g}}$ & $0.00^{\mathrm{h}}$ & $0.00^{1}$ & $0.00^{\mathrm{g}}$ & $0.00^{\mathrm{h}}$ & $0.20^{\mathrm{h}}$ \\
LSD & $0.78^{* * *}$ & $0.13^{* * *}$ & $1.56^{* * *}$ & $0.22^{* * *}$ & $0.06^{* * *}$ & $0.03^{* * *}$ & $0.04^{* * *}$ & $7.46^{* * *}$ \\
\hline
\end{tabular}

(1): The differences between the averages are shown in separate letters. (2): ***:P<0.001; **:P<0.01

Table 7. Correlation coefficients of several fruit quality properties $(\mathrm{P}=0.05)$.

\begin{tabular}{l|cc}
\multicolumn{1}{c|}{ Trait } & V2 & V3 \\
\hline TSS (V1) & 0.64 & 0.45 \\
Total Sugar (V2) & & 0.40 \\
Total Carotenoid (V3) & & 1 \\
\hline
\end{tabular}

*Significant coefficients, at 0.05 , are shown in bold. 
Biplot (axes F1 and F2: $86.37 \%$ )

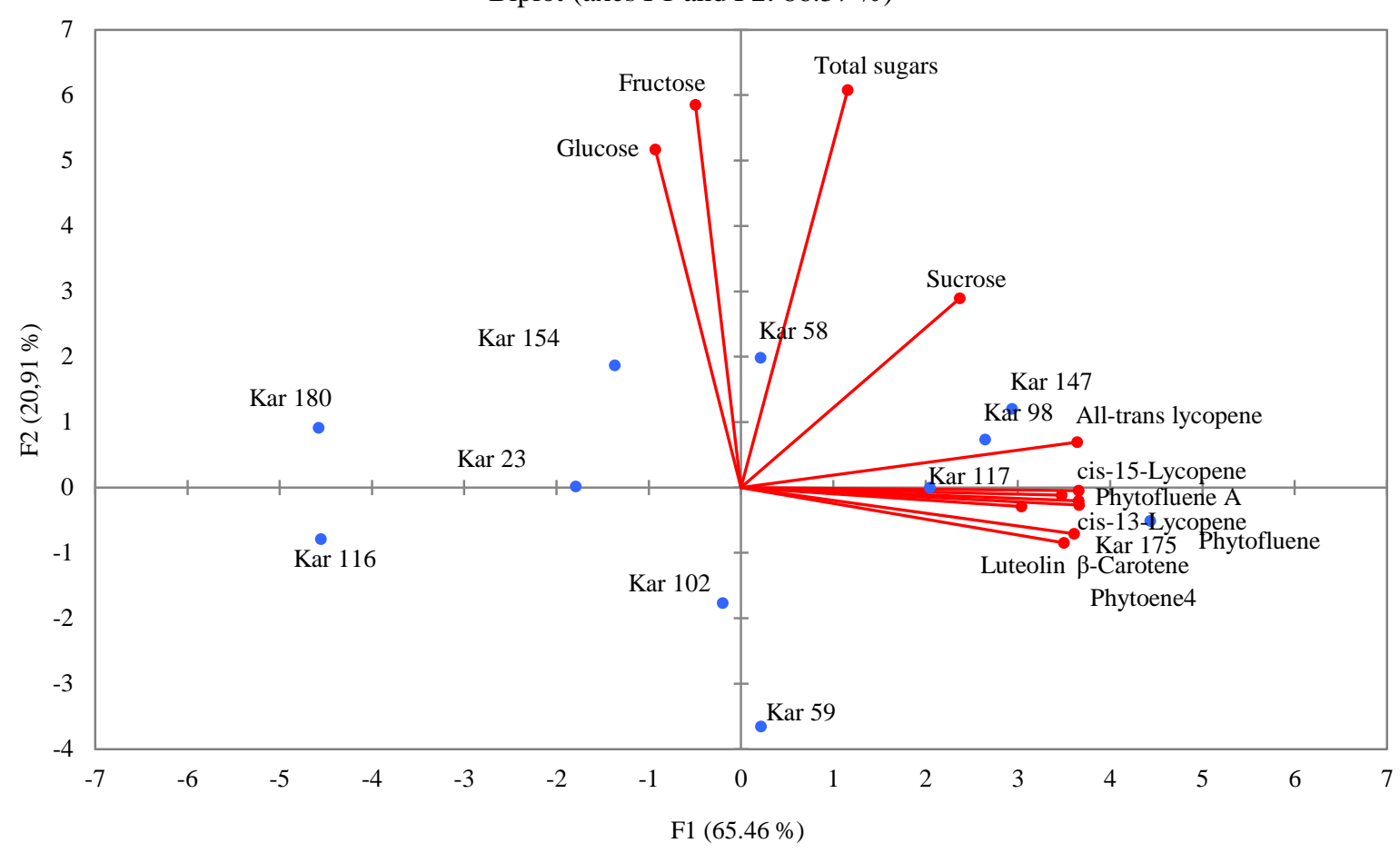

Figure 1b. Principal components analysis biplot for the first two principal components of watermelon composition

\section{Conclusion}

As a conclusion, this study revealed that selected watermelon genotypes have high diversity in terms of measured plant and fruit characteristics. With regard to carotenoid and sugar compositions of watermelon genotypes, one group was obtained characterizing the watermelons by PCA based on the genotype. Results obtained in this study extend our knowledge about the composition of watermelon genotypes from different origins. The future breeding strategy is to develop new varieties having high quality in fruit traits with a high content of sugars and carotenoids. Finally, the data generated by this study can potentially help Turkey agronomists to achieve the success of cultivating high-quality watermelon.

\section{Acknowledgements}

This research was supported by Cukurova University, Unit of Scientific Research Projects (Project no: FYL2015-5231)

\section{References}

Erdem Y, Yüksel AN, Orta AH. 2001. The Effects of Defficit Irrigation on Watermelon Yield, Water Use and Quality Characteristics. Pakistan Journal of Biological Sciences, 4(7): 785-789.

FAO, 2019. Year Production, Statistics, FAOSTAT, Watermelon Production, http://faostat.fao.org/default.aspx

Gichimu BM, Owuor BO, Dida MM. 2008. Agronomic Performance of Three Most Popular Commercial Watermelon Cultivars in Kenya as Compared to One Newly Introduced Cultivar and Local Landrace Grown on Dystrict Nitisols under Sub-Humid Tropical Conditions. Journal of Agricultural and Biological Science, 3(5/6): 65-71.

Gusmuni JR, Schultheis J, Wehner T. 2004. Rind Thickness of Watermelon Cultivars for Use in Pickle Production. HortTechnology, 14(4): 540-545.
Ilahy R, Tlili I, Siddiqui MW, Hdider C, Lenucci MS. 2019. Inside and Beyond Color: Comparative Overview of Functional Quality of Tomato and Watermelon Fruits. Front. Plant Sci., 10: 769. doi: 10.3389/fpls.2019.00769

Karipçin MZ. 2009. Yerli ve Yabani Karpuz Genotiplerinde Kuraklığa Toleransın Belirlenmesi. Doktora Tezi, Çukurova Üniversitesi Fen Bilimleri Enstitüsü, Adana, Turkey.

Kelebek H, Selli S, Kadiroglu P, Kola O, Kesen S, Ucar B, Cetiner B. 2017. Bioactive Compounds and Antioxidant Potential in Tomato Pastes as Affected by Hot and Cold Break Process. Food Chemistry, 220: 31-41.

Kim CH, Park MK, Kim SK, Cho YH. 2014. Antioxidant Capacity and Anti-inflammatory Activity of Lycopene in Watermelon. International Journal of Food Science and Technology, 49(9): 2083-2091.

Krasteva L. 2000. Watermelon Genetic Resources in Bulgaria. Acta Horticulturae, 510: 253-256.

Kumar CS, Mythily R, Chandraju S. 2012. Studies on Sugars Extracted from Watermelon (Citrullus lanatus) Rind, A Remedy for Related Waste and its Management. International Journal of Chemical and Analytical Science, 3(8): 15271529.

Li H, Deng Z, Liu R, Young, JC, Zhu H, Loewen S, Tsao R. 2011. Characterization of Phytochemicals and Antioxidant Activities of a Purple Tomato (Solanum lycopersicum L.). Journal of Agricultural and Food Chemistry, 59: 1180311811.

Liu C, Zhang H, Dai Z, Liu X, Liu Y, Deng X, Chen F, Xu J. 2012. Volatile Chemical and Carotenoid Profiles in Watermelons [Citrullus vulgaris (Thunb.) Schrad (Cucurbitaceae)] with Different Flesh Colors. Food Science and Biotechnology, 21(2): 531-541.

Maggs-Kolling GL, Christiansen JL. 2003. Variability in Namibian Landraces of Watermelon (Citrullus lanatus L.). Euphytica, 132(3): 251-258.

Perkins-Veazie P, Collins JK, Davis AR, Roberts W. 2006. Carotenoid Content of 50 Watermelon Cultivars. Journal of Agricultural and Food Chemistry, 54: 2593-2597. 
Sari N, Solmaz I, Unlu H, Yetisir H. 2007. Watermelon Genetic Resources in Turkey and Their Characteristics. Acta Horticulturae, 731: 433-438.

Schulteis JR, Thompson WB, Jester WB, Hassell RL. 2007. Mini Triploid Watermelon Cultigen Evaluations for Yield and Quality and Marketing in the United States. In: Conchie R.Mc, Rogers G (editors). Proc. IIIrd ISHS on Cucurbits, 731: 171-182.

Solmaz I, Sar1 N. 2009. Characterization of Watermelon (Citrullus lanatus) Accessions Collected from Turkey for Morphological Traits. Genetic Resources and Crop Evolution, 56(2): 173-188.

Solmaz I, Sari N, Aka-Kacar Y, Yalcin-Mendi NY. 2010. The Genetic Characterization of Turkish Watermelon Accessions Using RAPD Markers. Genetic Resources and Crop Evolution, 57: 763-771.
Solmaz I, Sarı N, Tarım G, Acembekiroğlu M, Pehlivan M. 2012. Determining the Agronomic Characteristics of Turkish Watermelon Genotypes for Developing Breeding Lines. Cucurbitaceae 2012, ss. 368-373.

Tanksley SD, Mccouch SR. 1997. Seed Banks and Molecular Maps: Unlocking Genetic Potential from the Wild. Science, 277: 1063-1066.

Yoo KS, Bang H, Lee EJ, Crosby K, Patil BS. 2012. Variation of Carotenoid, Sugar and Ascorbic Acid Concentrations in Watermelon Genotypes and Genetic Analyses. Horticulture Environment and Biotechnology, 53(6): 552-560.

Yuan-feng Z, Xuan-min D, Zhang X. 2013. A New Miniwatermelon F1 Hybrid- 'Qiongli'. Tropical Crops Genetic Resources Institute of Chinese Academy of Tropical Agricultural Sciences, Key Laboratory of Crop Gene Resources and Germplasm Enhancement in Southern China, Ministry of Agriculture. 24: 76-78.

Zhao W, Lv P, Gu H. 2013. Studies on Carotenoids in Watermelon Flesh. Agricultural Science, 4(7A): $13-20$ 